\title{
Cerebrospinal fluid tumour markers in patients treated for meningeal malignancy
}

\author{
Anton P van Zanten, Albert Twijnstra, Bram W Ongerboer de Visser, \\ Peter van Heerde, Augustinus A M Hart, William J Nooyen
}

\begin{abstract}
The results of cerebrospinal fluid (CSF) biochemical markers were compared with conventional CSF cytology in patients treated for leptomeningeal metastases from extra cranial malignancies. For lumbar CSF, before treatment, no statistically significant difference of the probabilities of being positive was found between CSF cytology and a classification by linear discriminant analysis, based on patient's age, of $\beta$ glucuronidase and $\beta_{2}$-microglobulin. During treatment, classification by linear discriminant analysis was found more often positive than cytology. Possible mechanisms for this difference are discussed. For ventricular CSF a correlation was found between CSF cytology and $\beta$-glucuronidase for solid tumours, and between CSF cytology and $\beta_{2-}$ microglobulin for haematological malignancies. Reference values for ventricular protein, CEA $\beta$-glucuronidase and $\beta_{2}$-microglobulin were obtained for cytological negative samples.
\end{abstract}

The diagnosis of leptomeningeal metastasis is usually established by the demonstration of tumour cells in the cerebrospinal fluid (CSF). Occasionally, the failure to demonstrate tumour cells in the CSF of patients with the clinical signs and symptoms of leptomeningeal metastasis constitutes a difficult diagnostic problem. $^{12}$ Diagnostic tools, such as the determination of CSF tumour markers, offering the possibility of an early detection of leptomeningeal metastasis, have been the subject of several studies. . $^{3-14}$

As intrathecal chemotherapy may be effective in countering meningeal spread of some tumours, markers are also needed during follow up studies, particularly because clinical evaluation may be difficult when irreversible damage to the nervous system has happened.

In previous studies ${ }^{3-7}$ we estimated the test characteristics sensitivity and specificity for the detection of meningeal malignancy of several biochemical markers in lumbar cerebrospinal fluid. We found that $\beta$ glucuronidase and $\beta_{2}$-microglobulin were the most useful markers for meningeal spread from solid tumours and haematological malignancies, respectively.

With the introduction of the use of the Ommaya device in the treatment of leptomen- ingeal metastasis, the ventricular C.SF became readily available for analysis of the biochemical markers. In this study we analysed the results of the markers carcinoembryonic antigen (CEA), $\beta$-glucuronidase, lactate dehydrogenase (LDH), $\beta_{2}$-microglobulin and of routine glucose and total protein, during therapy in relation to the findings of lumbar and ventricular CSF cytology.

\section{Methods}

Twenty five patients were referred to the Netherlands Cancer Institute for treatment. The primary site of malignancy, the follow up period and the number of CSF samples for each patient are given in table 1 . The diagnosis of leptomeningeal metastasis was confirmed in all cases by a positive CSF cytology.

Three patients were already being treated when this study started. All patients were treated with intraventricular methotrexate (MTX), six patients in combination with cranial radiotherapy. No steroids or other symptomatic treatments were used. None of the patients is still being treated.

Ventricular and lumbar punctures were carried out as part of the diagnostic and treatment procedures but not for the measurements of the markers alone. To obtain ventricular CSF, the Ommaya reservoir was inserted with a 23 gauge butterfly needle. Three ml of CSF, which had passed through the reservoir and tubing was withdrawn and discarded. An additional $7 \mathrm{ml}$ was then removed from the ventricle for the purpose of sampling. When clinically necessary, a total of $10 \mathrm{ml} \mathrm{CSF}$ was also removed by lumbar puncture one hour after the sampling from the Ommaya reservoir.

For cytological examination, slides were prepared by the cytocentrifuge technique (Shandon Elliot cytospin). The slides were airdried, fixed in methanol and routinely stained with Giemsa.

After centrifuging the samples, glucose, protein and LDH were determined immediately. Protein was measured using an adaptation on the ACA of the trichloroacetic acid procedure described by Meulemans. ${ }^{15}$ Glucose was measured enzymatically with an oxygen electrode (Beckman Instruments, Fullerton, USA). LDH was determined with the Automated Clinical Analyzer test method, calibrated to give values comparable with the method of the German Society for Clinical Chemistry. ${ }^{4}$ Additional samples were coded 
Table 1 Patients treated for leptomeningeal spread from solid tumours and haematological malignancies

\begin{tabular}{|c|c|c|c|c|c|c|c|c|}
\hline \multirow[b]{3}{*}{ Patient } & \multirow[b]{3}{*}{ Sex/Age } & \multirow[b]{3}{*}{ Tumour } & \multirow[b]{3}{*}{ Follow Up } & \multicolumn{5}{|c|}{ Number of CSF Samples } \\
\hline & & & & \multicolumn{3}{|c|}{ Lumbar } & \multicolumn{2}{|c|}{ Ventricular } \\
\hline & & & & Cyt & + & - & + & - \\
\hline 1 & $\mathrm{~F} / 22$ & ALL & 203 & & - & - & 1 & 5 \\
\hline 2 & $\mathrm{M} / 52$ & M Hodgkin & 47 & & 1 & 1 & 3 & 4 \\
\hline 3 & $M / 61$ & NHL & 36 & & - & - & 4 & 1 \\
\hline 4 & $\mathrm{M} / 49$ & NHL & 50 & & 1 & 1 & 6 & 1 \\
\hline 5 & $\mathrm{~F} / 70$ & $\mathrm{NHL}$ & 46 & & - & - & - & 5 \\
\hline 6 & $\mathrm{M} / 51$ & NHL & 11 & & 2 & - & 3 & - \\
\hline 7 & $\mathbf{M} / 34$ & NHL & 116 & & 2 & 2 & 3 & 7 \\
\hline 8 & M/69 & NHL & 32 & & 1 & 1 & 6 & 2 \\
\hline 9 & $\mathrm{~F} / 68$ & Breast & 50 & & 2 & 1 & 2 & 9 \\
\hline 10 & $\mathrm{~F} / 43$ & Breast & 212 & & 2 & 3 & 2 & 7 \\
\hline 11 & $F / 63$ & Breast & 18 & & $1^{\circ}$ & 2 & - & 3 \\
\hline 12 & $\mathrm{~F} / 69$ & Breast & 463 & & 2 & - & 11 & 10 \\
\hline 13 & $\mathrm{~F} / 45$ & Breast & 195 & & 1 & - & 1 & 7 \\
\hline 14 & $\mathrm{~F} / 50$ & Breast & 973 & & - & 2 & 4 & 23 \\
\hline 15 & $\mathrm{~F} / 50$ & Breast & 70 & & 2 & 2 & 2 & 7 \\
\hline 16 & $\mathrm{~F} / 59$ & Breast & 151 & & $\overline{3}$ & 3 & 3 & 11 \\
\hline 17 & F/57 & Breast & 64 & & 3 & - & 8 & - \\
\hline 18 & $F / 32$ & Breast & 187 & & 2 & - & 4 & 4 \\
\hline 19 & $F / 48$ & Breast & 182 & & 4 & - & 4 & 13 \\
\hline 20 & $\mathbf{F} / 62$ & Breast & 63 & & 2 & 5 & - & 11 \\
\hline 21 & $\mathrm{~F} / 52$ & Breast & 835 & & 2 & 1 & 19 & 10 \\
\hline 22 & $\mathrm{M} / 54$ & SCLC & 52 & & 1 & 5 & 1 & 10 \\
\hline 23 & $\mathrm{~F} / 45$ & Non-SCLC & 133 & & 2 & - & 6 & 8 \\
\hline 24 & $M / 31$ & Melanoma & 29 & & 3 & - & 10 & - \\
\hline \multirow{2}{*}{$\begin{array}{l}25 \\
\text { Total }\end{array}$} & $\mathrm{F} / 48$ & Melanoma & 22 & & 1 & - & 4 & 1 \\
\hline & & & & & 40 & 29 & 107 & 159 \\
\hline
\end{tabular}

The follow up period is defined as the number of days between the submission of the first and last CSF sample. ALL indicates acute lymphatic leukemia; NHL, non-Hodgkin lymphoma; SCLC, small cell lung carcinoma.

and stored at $-20^{\circ}$ C. $\beta$-glucuronidase was measured with phenolphthalein glucuronide as substrate. ${ }^{3}$

$\beta_{2}$-microglobulin was determined by radioimmunoassay with the Phadebas $\beta_{2}$ Micro Test ${ }^{5}$ and CEA levels with a modification $^{6}$ of the method described by Persijn and Korsten. ${ }^{16}$ Our laboratory reference values for lumbar CSF are: protein $0 \cdot 14-0.51 \mathrm{~g} / \mathrm{l} ;$ glucose $2.5-4.2 \mathrm{mmol} / \mathrm{l} ; \mathrm{LDH}$ $0-26 \mathrm{U} / \mathrm{l} ; \quad \beta$-glucuronidase $\quad 9-27 \mathrm{mU} / \mathrm{l}$; $\beta_{2}$-microglobulin (standardised to age) $0.65-2.20 \mathrm{mg} / \mathrm{l} ; \mathrm{CEA}<4 \mu \mathrm{g} / \mathrm{l}$.

In a previous study ${ }^{17}$ stepwise linear discriminant analysis (LDA) was carried out to classify the lumbar CSF samples into two categories: leptomeningeal spread present or absent. The discriminant functions for this analysis were generated from observations on a total of 265 patients, with metastatic and non metastatic diseases. In this study, the patients were classified by evaluating the scores obtained by the discriminant score functions from the previous study and assigning the patient to the group whose discriminant score function had the maximum score, that is, leptomeningeal spread present or absent.

The ventricular samples from each patient were divided into two categories, positive and

Table 2 Comparison of assay results in lumbar and ventricular CSF obtained at the same day

\begin{tabular}{|c|c|c|c|c|c|c|c|}
\hline \multirow[b]{2}{*}{ Analysis } & \multirow[b]{2}{*}{ No } & \multicolumn{3}{|c|}{ Lumbar CSF } & \multicolumn{3}{|c|}{ Ventricular CSF } \\
\hline & & Mean & Median & $(S D)$ & Mean & Median & $(S D)$ \\
\hline $\begin{array}{l}\text { Protein }(\mathrm{g} / \mathrm{l}) \\
\text { Glucose }(\mathrm{mmol} / \mathrm{l}) \\
\text { LDH }(\mathrm{U} / \mathrm{l}) \\
\beta \text {-glucuronidase }(\mathrm{mU} / \mathrm{l}) \\
\beta \text {-microglobulin }(\mathrm{mg} / \mathrm{l}) \\
\mathrm{CEA}(\mu \mathrm{g} / \mathrm{l})\end{array}$ & $\begin{array}{l}26 \\
26 \\
25 \\
22 \\
23 \\
23\end{array}$ & $\begin{array}{r}2 \cdot 32 \\
3 \cdot 56 \\
81 \cdot 20 \\
80 \cdot 86 \\
2 \cdot 56 \\
10 \cdot 40\end{array}$ & $\begin{array}{r}1 \cdot 70 \\
3 \cdot 60 \\
54 \cdot 00 \\
46 \cdot 50 \\
2 \cdot 09 \\
3 \cdot 10\end{array}$ & $\begin{array}{c}(1 \cdot 72) \\
(1 \cdot 01) \\
(65 \cdot 0) \\
(134 \cdot 3) \\
(1 \cdot 28) \\
(26 \cdot 5)\end{array}$ & $\begin{array}{r}0 \cdot 66 \\
4 \cdot 00 \\
18 \cdot 50 \\
19 \cdot 27 \\
1 \cdot 29 \\
7 \cdot 92\end{array}$ & $\begin{array}{r}0 \cdot 49 \\
3 \cdot 80 \\
15 \cdot 00 \\
14 \cdot 50 \\
0.93 \\
2 \cdot 30\end{array}$ & $\begin{array}{r}(0.66) \\
(0.80) \\
(18.00) \\
(15.60) \\
(0.81) \\
(25.61)\end{array}$ \\
\hline
\end{tabular}

Table 3 Comparison of the results of an allocation based on LDA of the combination of patients' age,

$\beta$-glucuronidase and $\beta_{2}$-microglobulin with cytology in lumbar CSF samples, obtained prior to treatment

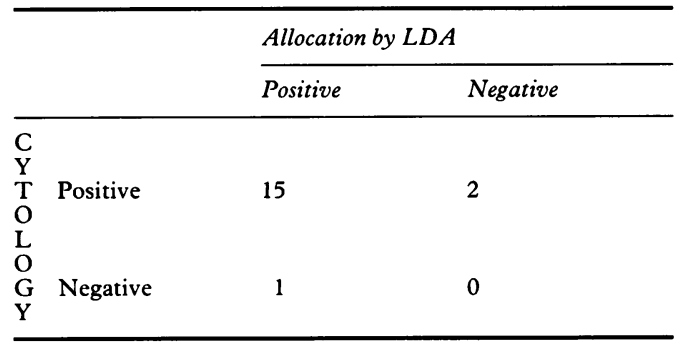

negative cytology, on the basis of cytological analysis. Differences between categories were evaluated with the two tailed, paired Wilcoxon test.

\section{Results}

For 28 paired samples, obtained from 13 patients, a comparison could be made between lumbar and ventricular CSF, obtained at the same day. In 22 cases, the results of lumbar and ventricular cytology were similar (15 negative and seven positive). In five cases the lumbar cytology was positive, although ventricular cytology was negative. In only one case did a positive ventricular cytology coincide with a negative lumbar cytology. The difference between lumbar and ventricular CSF cytology was not statistically significant (McNemar $p=0 \cdot 22$ ).

In lumbar CSF values for protein, $\mathrm{LDH}, \beta$ glucuronidase, $\beta_{2}$-microglobulin, and CEA were higher than those measured in the ventricular CSF. In contrast, ventricular CSF showed the highest glucose values (table 2).

By an allocation procedure, based on LDA of the combination of patient's age and the marker values for $\beta$-glucuronidase and $\beta_{2}$ microglobulin in lumbar CSF, it was possible to allocate the lumbar CSF samples in two categories, that is, meningeal spread present or absent. Table 3 presents the results for 18 samples obtained at diagnostic puncture. In 32 lumbar samples, obtained during follow up (table 4) a statistically significant difference was found (McNemar P $=0.036$ ) between the probability to be positive by LDA classification and cytology. In three of the 12 samples, with positive markers and negative cytology, there was evidence of infectious complications. By omitting these samples from the statistical

Table 4 Comparison of the results of an allocation based on LDA of the combination of patients' age,

$\beta$-glucuronidase and $\beta_{2}$-microglobulin with cytology in lumbar CSF samples, obtained during treatment

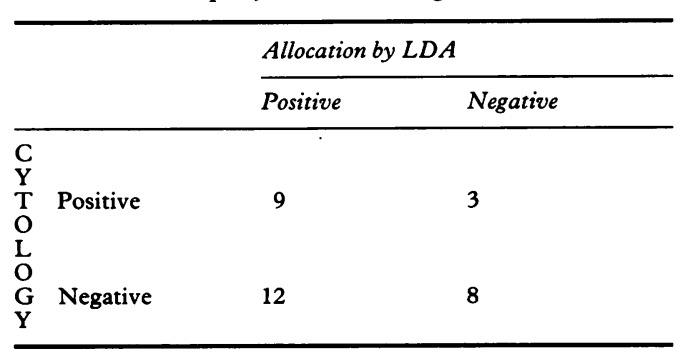


Table 5 Mean values for the various parameters in ventricular CSF of patients treated for leptomeningeal metastases

\begin{tabular}{|c|c|c|c|c|c|c|c|c|c|c|c|c|}
\hline $\begin{array}{l}\text { Patient } \\
\text { no }\end{array}$ & $\begin{array}{l}\text { Protein } \\
+ \\
g / l\end{array}$ & - & $\begin{array}{l}\text { Glucose } \\
+ \\
\text { mmol/l }\end{array}$ & - & $\begin{array}{l}L D H \\
\stackrel{+}{U} / l\end{array}$ & - & $\begin{array}{l}\beta \text {-glu } \\
+ \\
m U / l\end{array}$ & $\begin{array}{c}\text { midase } \\
-\end{array}$ & $\begin{array}{l}\beta_{2}-m i \\
+ \\
m g / l\end{array}$ & lobulin & $\begin{array}{l}C E A \\
+ \\
\mu g / l\end{array}$ & - \\
\hline $\begin{array}{r}1 \\
2 \\
3 \\
4 \\
5 \\
6 \\
7 \\
8 \\
9 \\
10 \\
11 \\
12 \\
13 \\
14 \\
15 \\
16 \\
17 \\
18 \\
19 \\
20 \\
21 \\
22 \\
23 \\
24 \\
25\end{array}$ & $\begin{array}{l}0.23 \\
0.25 \\
0.30 \\
0.48 \\
\text { na } \\
0.55 \\
0.83 \\
0.82 \\
0.43 \\
0.46 \\
\text { na } \\
0.33 \\
0.41 \\
0.49 \\
0.19 \\
0.78 \\
0.25 \\
0.19 \\
0.51 \\
\text { na } \\
1.38 \\
0.29 \\
0.20 \\
0.38 \\
0.65\end{array}$ & $\begin{array}{l}0 \cdot 32 \\
0 \cdot 47 \\
\text { na } \\
0 \cdot 36 \\
0 \cdot 39 \\
\text { na } \\
0 \cdot 50 \\
0 \cdot 50 \\
0 \cdot 76 \\
0 \cdot 29 \\
0 \cdot 39 \\
0 \cdot 33 \\
0 \cdot 27 \\
0 \cdot 57 \\
0 \cdot 55 \\
0 \cdot 32 \\
\text { na } \\
0 \cdot 18 \\
0 \cdot 55 \\
0 \cdot 89 \\
0 \cdot 89 \\
0 \cdot 17 \\
0 \cdot 24 \\
\text { na } \\
0 \cdot 40\end{array}$ & $\begin{array}{l}2 \cdot 60 \\
4 \cdot 77 \\
4.05 \\
3.83 \\
\mathrm{na} \\
4 \cdot 43 \\
4 \cdot 17 \\
3 \cdot 47 \\
4 \cdot 15 \\
4 \cdot 0 \\
\mathrm{na} \\
3.44 \\
3.80 \\
3.05 \\
4.70 \\
5.63 \\
3.45 \\
6 \cdot 12 \\
4.05 \\
\mathrm{na} \\
3.85 \\
4.70 \\
4.08 \\
3.58 \\
3.77\end{array}$ & $\begin{array}{l}3 \cdot 44 \\
4 \cdot 32 \\
\text { na } \\
4 \cdot 50 \\
4 \cdot 70 \\
\text { na } \\
4 \cdot 20 \\
3 \cdot 50 \\
4 \cdot 28 \\
3 \cdot 91 \\
3 \cdot 37 \\
3 \cdot 69 \\
3 \cdot 85 \\
3 \cdot 64 \\
4 \cdot 40 \\
5 \cdot 08 \\
\text { na } \\
3 \cdot 67 \\
4 \cdot 12 \\
3 \cdot 67 \\
4 \cdot 03 \\
4 \cdot 94 \\
4 \cdot 11 \\
\text { na } \\
4 \cdot 20\end{array}$ & $\begin{array}{r}1.0 \\
6.7 \\
44.5 \\
32.3 \\
\mathrm{na} \\
34.0 \\
11.3 \\
44.3 \\
21.0 \\
25.0 \\
\mathrm{na} \\
14.7 \\
26.0 \\
23.5 \\
3.5 \\
10.0 \\
20.0 \\
15.0 \\
10.0 \\
\mathrm{na} \\
15.6 \\
92.0 \\
11.3 \\
12.8 \\
7.5\end{array}$ & $\begin{array}{c}1 \cdot 2 \\
5 \cdot 7 \\
\text { na } \\
16 \cdot 0 \\
6 \cdot 8 \\
\text { na } \\
13 \cdot 4 \\
15 \cdot 0 \\
7 \cdot 3 \\
2 \cdot 3 \\
18 \cdot 7 \\
17 \cdot 0 \\
8 \cdot 6 \\
8 \cdot 7 \\
7 \cdot 9 \\
15 \cdot 9 \\
\text { na } \\
13 \cdot 0 \\
4 \cdot 9 \\
19 \cdot 4 \\
16 \cdot 6 \\
9 \cdot 6 \\
10 \cdot 7 \\
\text { na } \\
10 \cdot 0\end{array}$ & $\begin{array}{c}\text { na } \\
8 \cdot 7 \\
14 \cdot 5 \\
11 \cdot 6 \\
\text { na } \\
8 \cdot 0 \\
10 \cdot 5 \\
22 \cdot 0 \\
26 \cdot 0 \\
17 \cdot 0 \\
\text { na } \\
15 \cdot 5 \\
19 \cdot 0 \\
15 \cdot 3 \\
10 \cdot 5 \\
14 \cdot 0 \\
16 \cdot 4 \\
17 \cdot 0 \\
21 \cdot 3 \\
\text { na } \\
43.9 \\
49.0 \\
15.0 \\
15.4 \\
12.5\end{array}$ & $\begin{array}{c}8 \cdot 0 \\
8 \cdot 0 \\
\mathrm{na} \\
14 \cdot 0 \\
8 \cdot 6 \\
\mathrm{na} \\
14 \cdot 2 \\
19 \cdot 0 \\
24 \cdot 9 \\
10 \cdot 3 \\
21 \cdot 7 \\
14 \cdot 6 \\
12 \cdot 0 \\
15 \cdot 1 \\
10 \cdot 6 \\
11 \cdot 4 \\
\text { na } \\
11 \cdot 0 \\
12 \cdot 0 \\
26 \cdot 2 \\
30 \cdot 7 \\
16 \cdot 7 \\
14 \cdot 0 \\
\text { na } \\
10 \cdot 0\end{array}$ & $\begin{array}{l}0.92 \\
1.86 \\
1.91 \\
0.70 \\
\text { na } \\
4 \cdot 10 \\
3.73 \\
1.93 \\
1.32 \\
0.56 \\
\text { na } \\
1.21 \\
1.12 \\
1.71 \\
0.73 \\
1.05 \\
2.19 \\
0.81 \\
0.58 \\
\text { na } \\
1.44 \\
0.32 \\
3.06 \\
0.84 \\
0.68\end{array}$ & $\begin{array}{l}0.72 \\
1.05 \\
0.53 \\
0.43 \\
1.26 \\
\text { na } \\
1.64 \\
1.77 \\
2.30 \\
0.61 \\
1.53 \\
1.92 \\
1.20 \\
1.21 \\
1.07 \\
1.12 \\
\text { na } \\
0.82 \\
0.85 \\
1.91 \\
1.40 \\
0.32 \\
1.38 \\
\text { na } \\
0.44\end{array}$ & $\begin{array}{r}2 \cdot 20 \\
1 \cdot 18 \\
1.62 \\
2.30 \\
\text { na } \\
1.67 \\
2.00 \\
2.17 \\
2.25 \\
2 \cdot 15 \\
\text { na } \\
2.20 \\
2.65 \\
1.64 \\
1.80 \\
3.42 \\
85.64 \\
2.35 \\
2.34 \\
\text { na } \\
2.70 \\
2.00 \\
20.62 \\
2.49 \\
2.20\end{array}$ & $\begin{array}{c}1.99 \\
1.38 \\
2.11 \\
1.86 \\
1.68 \\
\mathrm{na} \\
1.74 \\
2.22 \\
3.12 \\
2.84 \\
3.38 \\
2.17 \\
2.21 \\
3.22 \\
2.54 \\
2.21 \\
\mathrm{na} \\
2.38 \\
2.16 \\
2.17 \\
2.78 \\
1.79 \\
13.54 \\
\mathrm{na} \\
1.40\end{array}$ \\
\hline
\end{tabular}

+ Indicates sample with positive cytology; - negative cytology na no value available

evaluation, the significance of the difference between LDA classsification and cytology decreased (McNemar $\mathrm{p}=0 \cdot 15)$.

The results of the determination of the marker values in ventricular CSF are presented in table 5. Considering only those patients with positive and negative cytology a significant difference between marker values in samples with positive and negative cytology (table 6) was only found for $\beta$-glucuronidase (Wilcoxon, $\mathrm{p}<0.01$ ) and $\beta_{2}$-microglobulin (Wilcoxon, $0.02<\mathrm{p} \leqslant 0.05)$ for solid tumours and haematological malignancies, respectively.

Reference values for ventricular CSF were estimated with Neumans' method. ${ }^{18}$ For this analysis all ventricular samples with a negative cytology were used. We found: protein $0 \cdot 10$ $0.28 \mathrm{~g} / \mathrm{l} ; \quad$ glucose $\quad 2.8-4.9 \mathrm{mmol} / \mathrm{l} ; \quad \beta$ glucuronidase $\quad 5-17 \mathrm{U} / 1 ; \quad \beta_{2}$-microglobulin $0 \cdot 22-1 \cdot 80 \mathrm{mg} / \mathrm{l}$; CEA $1 \cdot 0-2 \cdot 8 \mu \mathrm{g} / \mathrm{l}$. Reference values for $\mathrm{LDH}$ could not be calculated with Neuman's method. This was due to the many identical results measured by the ACA. This was caused by the low LDH activities measured in ventricular CSF and an electronic

Table 6 Mean and median of the results of biochemical markers in ventricular CSF for patients with positive as well as negative cytology

\begin{tabular}{|c|c|c|c|c|c|c|c|}
\hline Analysis & $\begin{array}{l}\text { No of } \\
\text { patien }\end{array}$ & Mean & Media & $n(S D)$ & Mean & Median & $(S D)$ \\
\hline \multicolumn{8}{|l|}{ Solid tumours } \\
\hline Protein, $\mathrm{g} / \mathrm{l}$ & 13 & 0.49 & 0.43 & $(0 \cdot 32)$ & 0.42 & 0.33 & $(0 \cdot 22)$ \\
\hline Glucose, $\mathrm{mmol} / \mathrm{l}$ & 13 & $4 \cdot 26$ & $4 \cdot 05$ & $(0.85)$ & $4 \cdot 15$ & $4 \cdot 11$ & $(0 \cdot 45)$ \\
\hline $\mathrm{LDH}, \mathrm{U} / 1$ & 13 & $21 \cdot 2$ & $15 \cdot 0$ & $(22 \cdot 4)$ & $10 \cdot 2$ & $9 \cdot 69$ & $(4 \cdot 45)$ \\
\hline$\beta$-glucuronidase, $\mathrm{mU} / 1$ & 13 & $21 \cdot 2$ & $17 \cdot 0$ & $(11.9)$ & $14 \cdot 9$ & $12 \cdot 0$ & $(6.20) p<0.01$ \\
\hline$\beta_{2}$-microglobulin, $\mu \mathrm{g} / 1$ & 13 & $1 \cdot 12$ & 1.05 & $(0 \cdot 70)$ & $1 \cdot 13$ & $1 \cdot 12$ & $(0.56)$ \\
\hline $\mathrm{CEA}, \mu \mathrm{g} / 1$ & 13 & $3 \cdot 72$ & $2 \cdot 25$ & $(5 \cdot 10)$ & $3 \cdot 26$ & $2 \cdot 38$ & $(3 \cdot 13)$ \\
\hline \multicolumn{8}{|c|}{ Haematological malignancies } \\
\hline Protein, $\mathbf{g} / 1$ & 5 & 0.52 & $0 \cdot 48$ & $(0 \cdot 29)$ & 0.43 & 0.47 & \multirow{6}{*}{$\begin{array}{l}(0.08) \\
(0.49) \\
(6.48) \\
(4.50) \\
(0.57) 0.02<p< \\
0.05 \\
(0.30)\end{array}$} \\
\hline Glucose, $\mathrm{mmol} / \mathrm{l}$ & 5 & $3 \cdot 77$ & $3 \cdot 83$ & $(0 \cdot 83)$ & 3.99 & $4 \cdot 25$ & \\
\hline $\mathrm{LDH}, \mathrm{U} / 1$ & 5 & $19 \cdot 1$ & $11 \cdot 3$ & $(18 \cdot 4)$ & $10 \cdot 3$ & $13 \cdot 4$ & \\
\hline$\beta$-glucuronidase, $\mathrm{mU} / \mathrm{l}$ & 4 & $13 \cdot 2$ & $13 \cdot 2$ & $(5.99)$ & $13 \cdot 8$ & $14 \cdot 1$ & \\
\hline$\beta_{2}$-microglobulin, $\mu \mathrm{g} / 1$ & & & 1.88 & $(1.07)$ & $1 \cdot 02$ & $0 \cdot$ & \\
\hline $\mathrm{CEA}, \mu \mathrm{g} / 1$ & 6 & $1 \cdot 91$ & $2 \cdot 08$ & $(0 \cdot 43)$ & $1 \cdot 88$ & 1.92 & \\
\hline
\end{tabular}

+ Indicates samples with positive cytology; -indicates negative cytology. The significance of + Indicates samples with positive cytology; -indicates negative cytology. The significance of
the difference between mean results in patients with a positive as well as a negative cytology was the difference between mean results in patients with a
calculated with the two tailed, paired Wilcoxon's test. circuit in the ACA, which produces only results which are multiples of two, for example, $0,2,4$, 6 , etc $\mathrm{U} / 1$.

\section{Discussion}

In evaluating the diagnostic value of CSF tumour markers in patients treated for leptomeningeal metastasis, there are several serious problems that need to be confronted. These are connected with the site of CSF puncture, the effects of therapy on blood/CSF barrier and with estimating reference values, particularly in ventricular CSF.

During the investigations leading to the diagnosis of leptomeningeal metastasis, it is usually lumbar CSF which is submitted to the clinical and cytological laboratory. During therapy, and after the installation of an Ommaya device, it is ventricular CSF which is usually submitted.

The composition of CSF can differ considerably between different CSF sources, such as the Ommaya reservoir or the lumbar space, even in the absence of an extra dural block. ${ }^{19}$ Reference values should therefore be estimated for lumbar and for ventricular CSF. For lumbar CSF, the methods for obtaining our reference values are described elsewhere. ${ }^{3-6}$ For ventricular CSF, the methods used for lumbar CSF cannot be used, mainly because of problems obtaining ventricular CSF for reference purposes. As only ventricular CSF from patients treated for their leptomeningeal metastases is submitted to our laboratory, we estimated the ventricular reference values with Neuman's method ${ }^{18}$ applied to the ventricular samples with a negative cytology.

From the literature ${ }^{20}$ it is known that results from CSF protein are influenced by the therapy used for the treatment of leptomeningeal metastases. It was also found ${ }^{21}$ that the administration of intrathecal methotrexate and CNS irradiation both affect endothelial pinocytosis, resulting in an increased transendoth- 
elial protein transport. The reference values for CSF protein, estimated by us in the ventricular CSF of patients treated for leptomeningeal metastasis, are somewhat higher than the published ventricular protein values ${ }^{22}$ but do, however, agree with the proposals by Livrea $e t$ $a l^{21}$ The reference values for ventricular glucose appeared reliable, compared with the observations by Fishman, ${ }^{23}$ who stated that the glucose content of ventricular CSF is usually higher than that of lumbar CSF. The $\beta_{2^{-}}$ microglobulin and $\beta$-glucuronidase content of ventricular CSF was lower than that of lumbar CSF.

In comparing our results with the reference procedure cytology, it is necessary to know the clinical value of this technique. At presentation this technique has a sensitivity of $59 \%,{ }^{1}$ but repeated puncture increased the sensitivity to $91 \% .{ }^{24}$ It has been argued that immunocytochemistry should be superior to conventional CSF cytology. ${ }^{25}$ However, in a group of 20 consecutive patients treated for leptomeningeal metastasis, we found no statistically significant difference between cytology and immunocytochemistry $^{26}$ (McNemar: p = 0.77). Differences between the two techniques were invariably found in samples with a low cell count. They were always based on a single or a few positive cells.

In a previous article ${ }^{17}$ we described the classification of lumbar CSF samples in two categories, leptomeningeal metastasis present or absent, using the patient's age and the results of $\beta$-glucuronidase and $\beta_{2}$-microglobulin. These CSF samples were from patients, not yet treated for their leptomeningeal metastases. Although care should be taken when applying a computer model where it has previously not been used, it was interesting to test the model on patients treated for their leptomeningeal metastases. As might be expected, the agreement between the classification by LDA and cytology, in patients not yet being treated, was good. In contrast a statistical significant difference was found between the two techniques in the lumbar samples of the patients during treatment for their leptomeningeal metastases. These differences may be caused by increased turnover in the CSF of serum proteins as a side effect of CNS irradiation or the administration of methotrexate. Otherwise it may be caused by infectious complications sometimes seen during the treatment of patients with leptomeningeal metastases.

For ventricular CSF we compared the test results of patients from whom samples with positive and negative cytology were submitted to the laboratory. In this way, the influence of three patients with only positive and three patients with only negative ventricular cytology was excluded from our evaluation. For ventricular CSF we found a statistically significant correlation between cytology and $\beta$ glucuronidase for solid tumours and between $\beta_{2}$-microglobulin and cytology for haematological malignancies. For $\beta_{2}$ microglobulin, our results in patients with haematological malignancies agree with those obtained by Storti et al. ${ }^{12}$ It should be noted that opinions vary about the clinical value of CSF $\beta_{2}$-microglobulin. ${ }^{13} 14$

In conclusion, when interpreting CSF tumour markers during therapy they should be compared with test results with a reference range estimated for a specific region of the neuraxis, and that bacterial or fungal infections in particular should be excluded from the diagnosis by careful bacteriological examination of the CSF. During therapy the measurements of CSF tumour markers are not superior to CSF cytology in samples with elevated cell counts. Perhaps CSF tumour markers are most useful in samples with low cell counts, although this subject merits further serious attention.

1 Glass JP, Melamed M, Chernik NL, Posner JB. Malignant cells in cerebrospinal fluid (CSF): The meaning of a positive CSF cytology. Neurology 1979;29:1369-75.

2 Ongerboer de Visser BW, Somers R, Nooyen WH, van Heerde P, Hart AAM, McVie JG. Intraventricular methotrexate therapy of leptomeningeal metastasis from breast carcinoma. Neurology 1983;33:1565-72.

3 van Zanten AP, Twijnstra A, van Benthem V, Hart AAM, Ongerboer de Visser BW. Cerebrospinal fluid $\beta$ glucuronidase activities in patients with central nervous gystem metastases. Clin Chim Acta 1985;147:127-34.

4 van Zanten AP, Twijnstra A, Hart AAM, Ongerboer de Visser BW. Cerebrospinal fluid lactate dehydrogenase Visser BW. Cerebrospinal fluid lactate dehydrogenase
activities in patients with central nervous system metastases. Clin Chim Acta 1986;161:259-68.

5 Twijnstra A, van Zanten AP, Nooyen WJ, Hart AAM, Ongerboer de Visser BW. Cerebrospinal fluid $\beta_{2}-$ microglobulin: a study in controls and patients with metastatic and non metastatic neurological diseases. Eur J Cancer Clin Oncol 1986;22:387-91.

6 Twijnstra A, Nooyen WJ, van Zanten AP, Hart AAM, Ongerboer de Visser BW. Cerebrospinal fluid carcinoembrionic antigen in patients with metastatic and non metastatic neurological diseases. Arch Neurol 1986;43:269-72.

7 van Zanten AP, Twijnstra A, Ongerboer de Visser BW. Routine investigations of the CSF with special reference to meningeal malignancy and infectious meningitis. Acta to meningeal malignancy and infel

8 Schold SC, Wasserstrom WR, Fleisher M, Schwartz MK, Posner JP. Cerebrospinal fluid biochemical markers of central nervous system metastasis. Ann Neurol 1980;8:597-604.

9 Shuttleworth EC, Allen N. CSF $\beta$-glucuronidase assay in the diagnosis of neoplastic meningitis. Arch Neurol 1980;37:684-7.

10 Tallman RD, Kimbrough SM, O'Brien JF, Goellner JR, Yanagihara T. Assay for $\beta$-glucuronidase in cerebrospinal fluid: Usefulness for the detection of neoplastic meningitis. Mayo Clin Proc 1985;60:293-8.

11 Jacobi C, Reiber H, Felgenhauer K. The clinical relevance of locally produced carcinoembrionic antigen in cerebrolocally produced carcinoembrionic an
spinal fluid. $J$ Neurol $1986 ; 233: 358-61$.

12 Storti S, Pagano L, Marra L, Teofilli BM, Ricerra GL, Bizzi B. Cerebrospinal fluid beta-2-microglobulin: a reliable B. Cerebrospinal fluid beta-2-microglobulin: a reliable
index of leukaemic infiltration of central nervous system. index of leukaemic infiltration of cen

13 Nagelkerke AF, van Kamp GJ, Veerman AJP, de Waal FC. Unreliability of $\beta_{2}$-microglobulin in early detection of central nervous system relapse in acute lymphoblastic leukemia. Eur J Cancer Clin Oncol 1985;21:659-63.

14 Pudek MR, Chan KW, Rogers PC, Teasdale JM. $\beta_{2}$ microglobulin levels in cerebrospinal fluid of children with leukemia and lymphoma. Clin Biochem 1985;18: 180-3.

15 Meulemans O. Determination of total protein in spinal fluid with sulphosalicylic acid and trichloracetic acid. Clin Chim Acta 1960;5:757-61.

16 Persijn JP, Korsten CB. The development of a radio immunoassay for carcino-embryonic antigen with some immunoassay for carcino-embryonic antigen with some

17 van Zanten AP, Twijnstra A, Ongerboer de Visser BW, Hart AAM, Nooyen WJ. Tumormarkers in the cerebrospinal fluid of patients with central nervous system metastases from extracranial malignancies. Clin Chim Acto $988 ; 175: 157-66$

18 Neuman GJ. The determination of normal ranges from routine laboratory data. Clin Chem 1968;14:979-88.

19 Murray JJ, Greco FA, Wolf SN, Hainsworth JD. Neoplastic meningitis marked variations of cerebrospinal fluid composition in the absence of extradural block. $A m \mathrm{~J} \mathrm{Med}$ 1983;75:289-94.

20 Duttera MJ, Bleyer WA, Pommeroy TC, Leventhal CM, Leventhal BG. Irradiation, methotrexate toxicity and the treatment of meningeal leukemia. Lancet 1973;ii:703-7.

21 Livrea P, Trojano M, Simone IL, et al. Acute changes in blood-CSF barrier perm selectivity to serum proteins 
after intrathecal methotrexate and CNS irradiation. $J$ Neurol 1985;231:336-9.

22 Fishman RA. Composition of cerebrospinal fluid. Cerebrospinal fluid in diseases of the nervous system. Philadelphia: WB Saunders, 1980:206

23 Fishman RA. Composition of cerebrospinal fluid. Cerebrospinal fluid in diseases of the nervous system. Philadelphia: $0: 211$

24 Wasserstrom WR, Glass JP, Posner JP. Diagnosis and treatment of leptomeningeal metastasis from solid tumours: experience with 90 patients. Cancer 1982;49:759-72.
25 Coakham HB, Garson JA, Brownell B, Kemshead JT Diagnosis of Cerebral Neoplasms Using Monoclonal Antibodies. In: Clifford Rose F, Fields WS, eds. Antibodies. In: Clifford Rose F, Fields WS, eds. Proceedings of the Mansell Bequest Symposium on Advances in Neuro-Oncology. Prog exp Tumor Res
(Basel)

1985;29:

26 Boogerd W, Vroom ThM, van Heerde P, Brutel de la Riviere G, Peterse JL, van der Sande JJ. CSF cytology versus immunocytochemistry in meningeal carcinomatosis. $J$ Neurol Neurosurg Psychiatry 1988;51:142-5. 